\title{
Monitoring of spotted eagles in Estonia in 1994-2014: Stability of the lesser spotted eagle (Aquila pomarina) and decline of the greater spotted eagle (A. clanga)
}

\author{
Monitorovanie orla krikl'avého a hrubozobého v Estónsku v rokoch 1994 až 2014: \\ Stabilita u orla krikl'avého (Aquila pomarina) a pokles u orla hrubozobého (A. clanga)
}

\author{
Ülo VÄLI
}

\begin{abstract}
Population trends of the lesser and greater spotted eagle in Estonia were comparatively estimated using data obtained in 1994-2014 from the monitoring scheme of common raptors and from special plots for monitoring of spotted eagles. Both approaches had pros and cons, but resulted in similar population trends. The numbers of the lesser spotted eagle have had minor fluctuations over the last two decades but the overall trend is stable; the current population size is estimated as $600-700$ pairs. The number of greater spotted eagle breeding territories (pure-species and mixed pairs pooled) have significantly decreased, for example by $14 \%$ per year in 2004-2010, though in recent years the numbers seem to be stabilised at a critically low level. The decline of pure-species pairs was somewhat steeper than that of mixed pairs, their proportion decreasing from a third to a quarter of the greater spotted eagle breeding territories. Altogether 5-10 breeding territories of the greater spotted eagle may be found nowadays in Estonia.
\end{abstract}

\begin{abstract}
Abstrakt: Populačné trendy orla krikl’avého a hrubozobého v Estónsku boli odhadnuté z údajov získaných v rokoch 1994 - 2014 v rámci monitoringu bežných druhov dravcov a tiež zo špeciálnych plôch na monitoring týchto dvoch druhov orlov. Oba metodické prístupy majú svoje klady a zápory, avšak z ich údajov vypočítané populačné trendy sú si podobné. Početnost’ orla krikl'avého v posledných dvoch desat'ročiach mierne kolísala, celkový trend je ale stabilný; vel'kost' jeho populácie sa v súčasnosti odhaduje na 600 - 700 párov. Počet hniezdnych teritórií orla hrubozobého (čisté aj zmiešané páry) významne poklesol, napr. v rokoch 2004 až 2010 o 14 \% za rok, v posledných rokoch sa ich počet zdá byt’ stabilizovaný na kriticky nízkej úrovni. Pokles početnosti čistých párov bol prudší než u zmiešaných párov, ich podiel sa znížil z tretiny na štvrtinu z hniezdnych teritórií orla hrubozobého. Dnes je v Estónsku možné nájst' 5 - 10 hniezdnych teritórií tohto druhu orla.
\end{abstract}

Key words: abundance, monitoring, numbers, population trend, raptor, permanent study plot

Ülo Väli, Department of Zoology, Estonian University of Life Sciences, Kreutzwaldi 5, 51014 Tartu, Estonia. E-mail: ulo.vali@emu.ee.

Acknowledgement: I am grateful to the members of the Raptor Study Group at the Estonian Ornithological Society and the Eagle Club for their invaluable effort during collecting data on the spotted eagles in the field for many years. Asko Lõhmus, Rein Nellis, Joosep Tuvi and Urmas Abel helped with compilation of data over the two decades. The monitoring of spotted eagles and other raptors has been financed by the Estonian Environmental Investments Centre and supported by the various subunits of the Estonian Ministry of the Environment. Data analysis and compilation of the current paper was supported by the Estonian Ministry of Education and Research (grant IUT21-1).

\section{Introduction}

The lesser spotted eagle (Aquila pomarina) and the greater spotted eagle (Aquila clanga) are closely-related palaearctic eagles whose ranges overlap in Eastern Europe. The lesser spotted eagle is the more numerous of the two species, but in recent decades its numbers show various trends across Europe (BirdLife International 2004, 2015). The greater spotted eagle has decreased all over its European range (BirdLife
International 2015) and nowadays it is one of the most threatened raptors on the continent. These reasons, accompanied with the alteration of greater spotted habitats (Maciorowski \& Mirski 2014) and flexibility in habitat use by the lesser spotted eagle (Lõhmus \& Väli 2005), have led to the extensive hybridisation of the two species (Väli et al. 2010a). Mixed pairs produce fertile offspring, which, at least nowadays, form a natural part of the population in the hybrid zone (Väli 2010, Väli et al. 2010a). 
Väli Ü: Monitoring of spotted eagles in Estonia in 1994-2014:
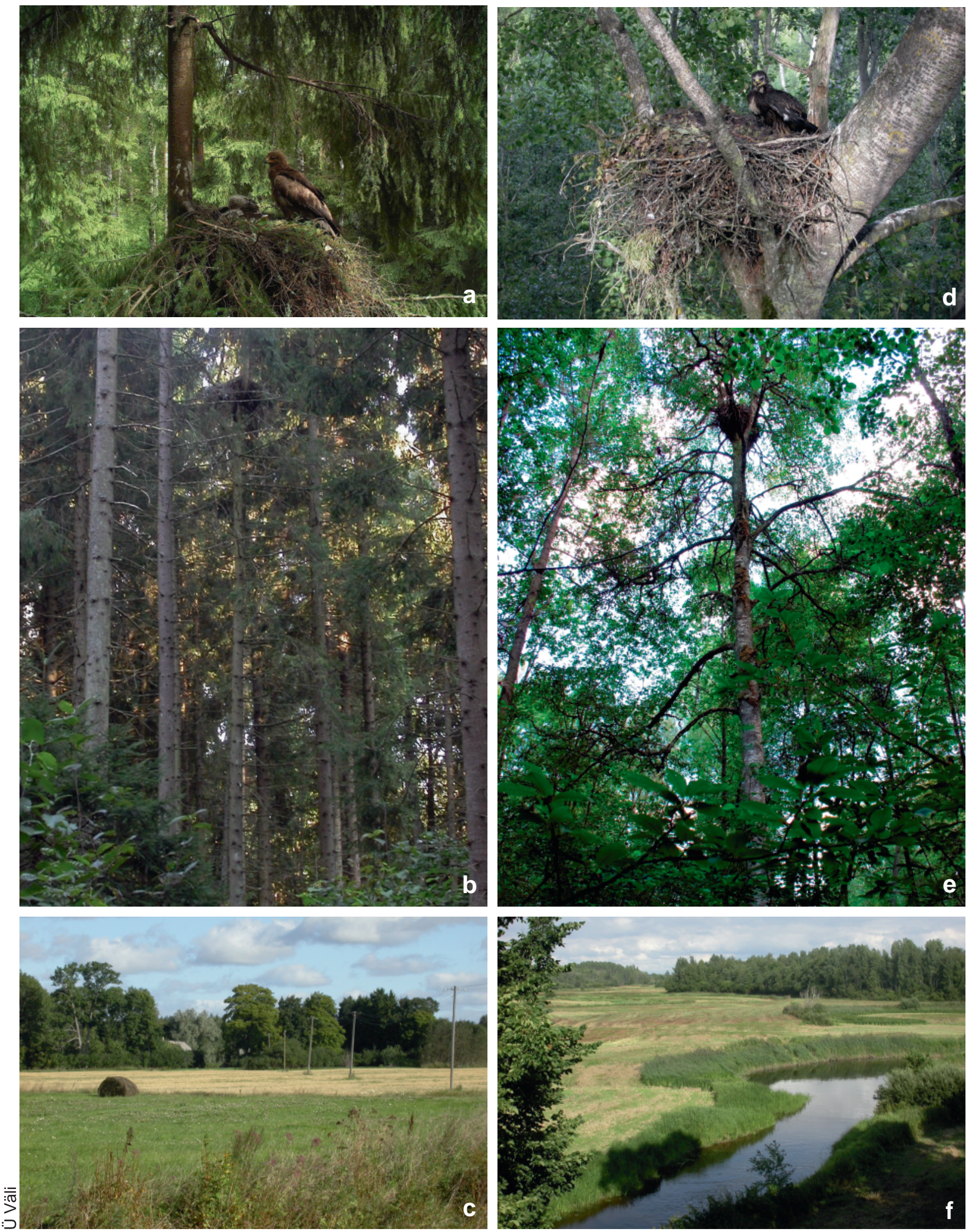
Both spotted eagle species breed in Estonia (Fig. 1). The first general estimations of their numbers here date back to the early 20th century, and the first quantitative estimates to the middle of the 20th century (Väli 2011). However, the numbers of the lesser spotted eagle were seriously underestimated up to the 1990s (Lõhmus \& Väli 2001b, Väli 2011) and those for the greater spotted eagle may have been biased due to misidentifications (Väli \& Lõhmus 2000). Not until 1997 did the compilation of data from many study plots across Estonia result in first reliable estimations: 480-600 pairs of lesser spotted eagles and 20-30 pairs of greater spotted eagles, also including mixed pairs (Lõhmus 1998, Lõhmus \& Väli 2001a, b). Since then the estimation for the lesser spotted eagle has been recalculated and corrected to 600-700 pairs (Elts et al. 2013). Reliability of the estimate is supported by the compilation of monitoring data and casual field observations; indeed, most of the population has been actually recorded in the field (Väli 2011). Also the estimate for the greater spotted eagle and mixed pairs has been changed to 5-10 pairs in 2012 (Elts et al. 2013) but, unlike for the lesser spotted eagle, actual decrease in numbers was the cause of the change in this species (Väli et al. 2010a, Väli 2011).

Monitoring of spotted eagles has a long history in Estonia. In the previous century spotted eagles were followed together with other birds of prey in permanent raptor monitoring plots. Several of such plots have been studied over decades (Randla 1976, Lelov 1991, Tuule et al. 2011), although only a few pairs of spotted eagles have been breeding there and thus trends have been difficult to estimate. The monitoring of raptors became more extensive in the early 1990s, and since 1994 the programme has been included in the national bird monitoring scheme (Lõhmus 1994). A modern raptor plot is usually a UTM-grid based square with average size of ca $100 \mathrm{~km}^{2}$, although some variation in shape and size exists (Lõhmus 1994, 2004). With the increasing number of raptor plots the coverage of spotted eagles improved significantly, although the grid of raptor plots still enabled researchers to follow only a limited sample of the eagles. To enhance the monitoring and studies on biology of spotted eagles, a special $1,000 \mathrm{~km}^{2}$ study area was established near Tartu in the early 1990s. In 2003 similar spotted eagle monitoring plots (200-600 $\mathrm{km}^{2}$ ) were also established in other parts of Estonia as part of the national monitoring of the lesser spotted eagle. Both schemes, the grid of raptor study plots and that of the spotted eagle plots, are still studied at present.

In the current study I use data from the two monitoring schemes and analyse trends in the two spotted eagle species, and mixed pairs, over the last two decades. I also discuss the pros and cons of the two approaches and thus bring the classical "single (few) large or several small (SLOSS)" debate to the discussion on the monitoring of spotted eagles.

\section{Methods}

The study was conducted in Estonia, north-eastern Europe (Fig. 2a), a lowland country situated in the hemiboreal vegetation zone and characterised by flat terrain. The area of the country is $45,215 \mathrm{~km}^{2}$ and approximately $50 \%$ of it is covered with forest. In Estonia, the lesser spotted eagle is at the northern limit of its range and the same is nearly true for the greater spotted eagle, except for a pair recorded in Finland (Valkama et al. 2011) and a small population in north-western Russia (Pchelintsev 2006). The species are distributed throughout the Estonian mainland, but the greater spotted eagle is very scarce throughout the country (Väli \& Lõhmus 2000, Väli et al. 2005) and breeding density of the lesser spotted eagle rises gradually from northwest to southeast (Lõhmus 1998, Lõhmus \& Väli 2001).

The current study includes data from the raptor monitoring plots (hereafter raptor plots) in 1994-2014 and from the larger special study plots, where only spotted eagles were monitored (hereafter spotted eagle plots), in 2003-2014 (Figure 2b). These two sources are analysed separately because of the differences in study periods and sizes of the plots, and moreover several raptor plots are included in the spotted eagle plots and thus should have been omitted from the united analysis to avoid pseudoreplication. As an exception among the spotted eagle plots, the survey plot near Tartu has provided reliable numbers of spotted eagles since 1997; the data from this study area are presented separately.

The number of annually studied raptor plots has varied between 8 and 19, spotted eagles being recorded in 5-12 of them, and their size has ranged from $25 \mathrm{~km}^{2}$

- Fig. 1. Typical habitats of spotted eagles in Estonia. The nest site (a, b) and the foraging habitat (c) of the lesser spotted eagle and the same habitats $(\mathrm{d}-\mathrm{f})$ of the greater spotted eagle.

- Obr. 1. Typické habitaty orla kriklavého a hrubozobého v Estónsku. Hniezdisko (a, b) a lovisko (c) orla kriklavého a tie isté habitaty orla hrubozobého $(d-f)$. 


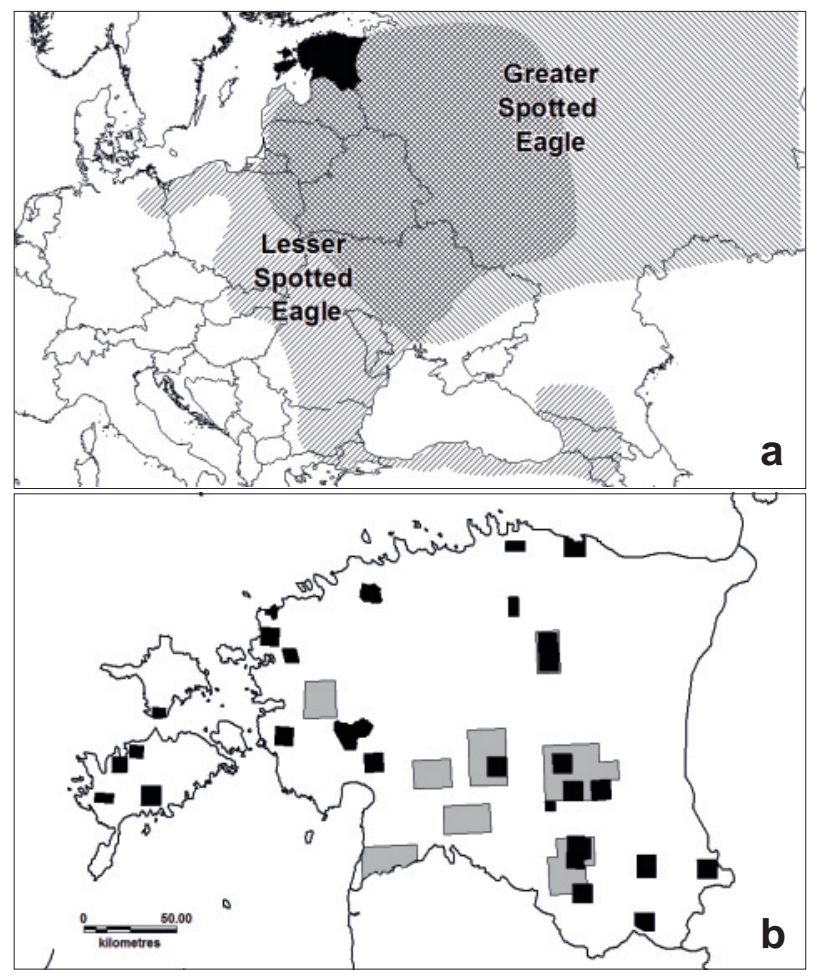

Fig. 2. The study region, Estonia (black), and approximate distribution ranges of the lesser spotted eagle and the greater spotted eagle in Europe (a). The locations of the raptor plots (black) and spotted eagle plots (grey) in Estonia (b).

Obr. 2. Študované územie, Estónsko (čierne) a približný areál výykytu orla kriklavého a hrubozobého v Európe (a). Rozmiestnenie monitorovacích plôch pre bežné druhy dravcov (čierne) a pre orla kriklavého a hrubozobého (sivo) v Estónsku (b).

to $200 \mathrm{~km}^{2}$ (mean $\left.=84 \pm 43(\mathrm{SD}) \mathrm{km}^{2}\right)$, total area being between $905 \mathrm{~km}^{2}$ and $1657 \mathrm{~km}^{2}$ (Figs 2 and 3). The total number of spotted eagle pairs in raptor plots was 11-21 annually. On the other hand, the number of annually studied special spotted eagle plots varied between four and seven, and their sizes between 200 and 1000 $\mathrm{km}^{2}\left(\right.$ mean $\left.=458 \pm 250 \mathrm{~km}^{2}\right)$; the total area ranged between 2000 and $3210 \mathrm{~km}^{2}$ (Figs 2 and 3). In total there were 64-104 pairs of spotted eagles recorded annually on these large special monitoring plots.

The field methods of spotted eagle monitoring were similar in the two types of plots. Spotted eagles were mapped throughout the breeding season in study areas using methodology similar as for other raptors (e.g. Hardey et al. 2009). This included observations of displaying birds in spring, and also later during the breeding season, registering birds on foraging and carrying

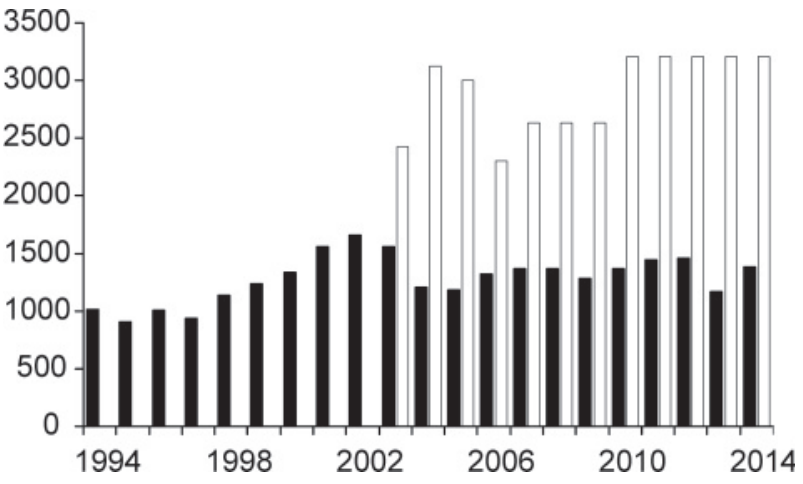

Fig. 3. Inter-annual dynamics of the total studied area $\left(\mathrm{km}^{2}\right)$ in raptor study plots (filled bars) and spotted eagle plots (empty bars).

Obr. 3. Medziročná dynamika výmery $\left(\mathrm{km}^{2}\right)$ územia monitorovaného $v$ rámci monitorovacích plôch pre bežné druhy dravcov (plné stĺpce) a pre orla kriklavého a hrubozobého (prázdne stípce).

food to their nests, searching for potential nests throughout the year and checking them at least once during the breeding season. Adult birds were identified in the field according to the characteristics described by Forsman (1999) and nestlings according to Väli \& Lõhmus (2004). Moreover, samples from adult birds (moulted feathers) and nestlings (blood and feather samples) were collected and genetic identification of species was performed according to Väli et al. (2010b). In addition to pure-species pairs, also mixed-species pairs were included in the current study, and to simplify analysis I pooled in this sample the ones involving a greater and a lesser spotted eagle, and also those including an F1 hybrid, F2 hybrid or a backcross to the pure species breeding with each other or with a bird from a parental species. The proportions of such hybridising pairs are not treated here, but see Väli et al. (2010a) and Väli (2011) for detailed analysis of the hybridisation. Population trends were analysed separately for the lesser spotted eagle and, due to the low numbers, jointly for the greater spotted eagle and mixed pairs. This grouping was justified also by the fact that mixed pairs have usually been established in the territories of the greater spotted eagle (Lõhmus \& Väli 2005).

In surveys where not all areas are studied throughout the period, registered raw annual average densities are influenced by the exchange of the study areas and do not reflect real changes. To avoid such bias, analysis of trends was based on imputed abundance indices calcu- 
lated using the TRIM program version 3.53 (Pannekoek \& Van Strien 2005). A time series model was applied, with serial correlation taken into account, and for the detailed analysis of trends a linear model with breakpoints was used. Fit of models was assessed with the likelihood ratio test, and difference of the slope from zero was analysed using the Wald test. Trends were visualised by linear trend line or by loess curve with $95 \%$ confidence intervals.

\section{Results}

The les s e r s p ot t e d e a g le

According to the indices, calculated using the data from raptor study plots (Fig. 4a), the lesser spotted eagle population was well characterised in 1994-2014 by a linear trend $(\Lambda=80.2, \mathrm{df}=145, \mathrm{P}=1.0$; i.e. linear model was not rejected). Although there seemed to be somewhat higher abundance in the 2000s compared to 1990 s, the standard errors were large and the slope of the trend was not significantly different from zero $(\Theta=10.6$, df $=19, \mathrm{P}=0.93)$; thus the population was considered as stable. The data from the spotted eagle plots (Fig. 4b) suggested the same for 2003-2014 $(\Lambda=11.0, \mathrm{df}=47, \mathrm{P}=1.0 ; \Theta=11.7, \mathrm{df}=10, \mathrm{P}=0.31)$, although there was a tendency for a decrease in 2004-2006 $(\Theta=4.0, \mathrm{df}=1, \mathrm{P}=0.04)$ and an increase after $2012(\Theta=2.24, \mathrm{df}=1, \mathrm{P}=0.13)$. At the best-studied spotted eagle plot near Tartu the annual number of lesser spotted eagle breeding territories has fluctuated between 20 and 26; numbers were somewhat underestimated in 2006-2008 when the study intensity was lower. Also there the overall trend of the lesser spotted eagle pairs could be considered as stable.

The mean density of the lesser spotted eagle in 1994-2014 in Estonia, as revealed by all raptor plots, was 1.03 pairs $/ 100 \mathrm{~km}^{2}$, and the annual densities fluctuated due to inter-annual changes in numbers of eagles and composition of plots between 0.58 and 1.34 pairs $/ 100 \mathrm{~km}^{2}$. To compare the two different study approaches, I also calculated densities in raptor plots where at least one lesser spotted eagle pair was breeding; the mean density was 1.23 pairs $/ 100 \mathrm{~km}^{2}$, inter-annual variation of mean density $0.98-1.88$ pairs $/ 100 \mathrm{~km}^{2}$ and variation between mean densities among plots 0.72-3.85 pairs $/ 100 \mathrm{~km}^{2}$. Comparatively, densities obtained from the spotted eagle plots varied between plots from 2.0 to 4.2 pairs $/ 100 \mathrm{~km}^{2}$ (mean $=2.8$ pairs $/ 100 \mathrm{~km}^{2}$ ) and yearly averages between 2.47 and
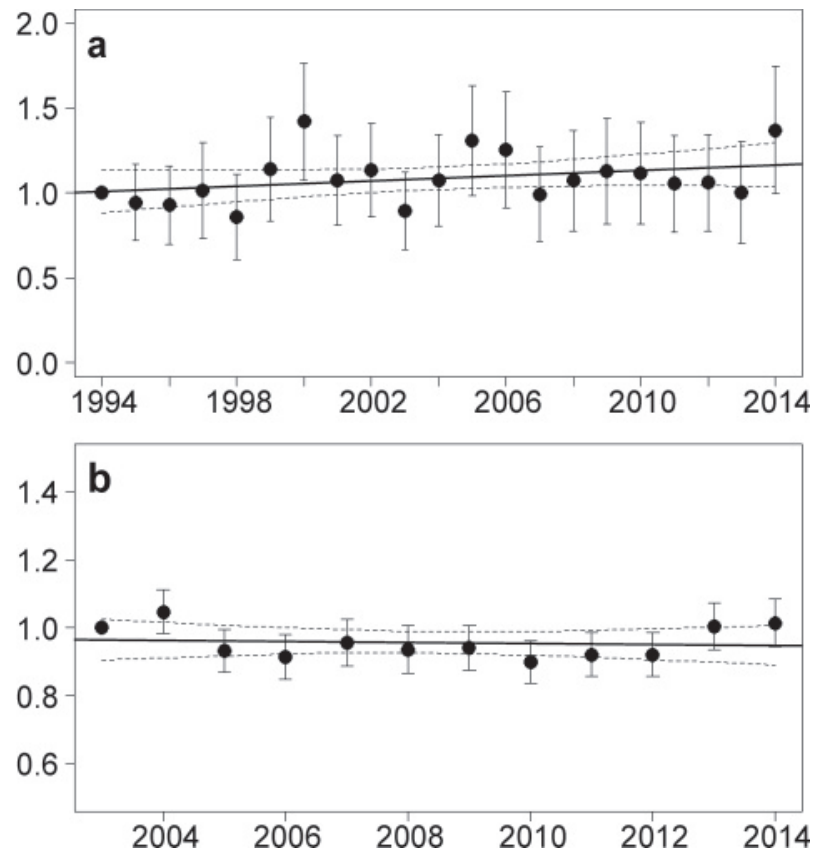

Fig. 4. Population dynamics of the lesser spotted eagle according to the data from raptor plots in 1994-2014 (a) and spotted eagle plots in 2003-2014 (b). Whiskers indicate standard errors of annual indices; linear trend with $95 \% \mathrm{Cl}$ is presented.

Obr. 4. Populačná dynamika orla kriklavého na základe údajov z monitorovacích plôch pre bežné druhy dravcov v rokoch 1994 - 2014 (a) a pre orla krikl'avého a hrubozobého v rokoch 2003 2014 (b). Úsečky predstavujú štandardnú chybu ročných populačných indexov; zobrazený je lineárny trend s $95 \%$ intervalom spol'ahlivosti.

3.34 pairs $/ 100 \mathrm{~km}^{2}$ (mean $=2.7$ pairs $\left./ 100 \mathrm{~km}^{2}\right)$, indicating that spotted eagle plots have been established in better than average areas.

The greater s pot t e d e a g le In 2003-2014 pure-species greater spotted eagle pairs were found in two and mixed pairs in six out of eight spotted eagle study plots. During that period the total number of pure-species pairs in spotted eagle plots decreased from four to one and mixed pairs from seven to four (Fig. 5a). According to the calculated population indices the number of greater spotted eagle breeding territories (pure-species and mixed pairs pooled) steeply declined in 2003-2014 $(\mathrm{P}<0.05)$. The strongest decline was recorded in 2004-2010 when the population decreased by $14 \%$ annually $(\Theta=11.2, \mathrm{df}=1, \mathrm{P}<0.001)$; since then the numbers seem to have stabilised at a very 

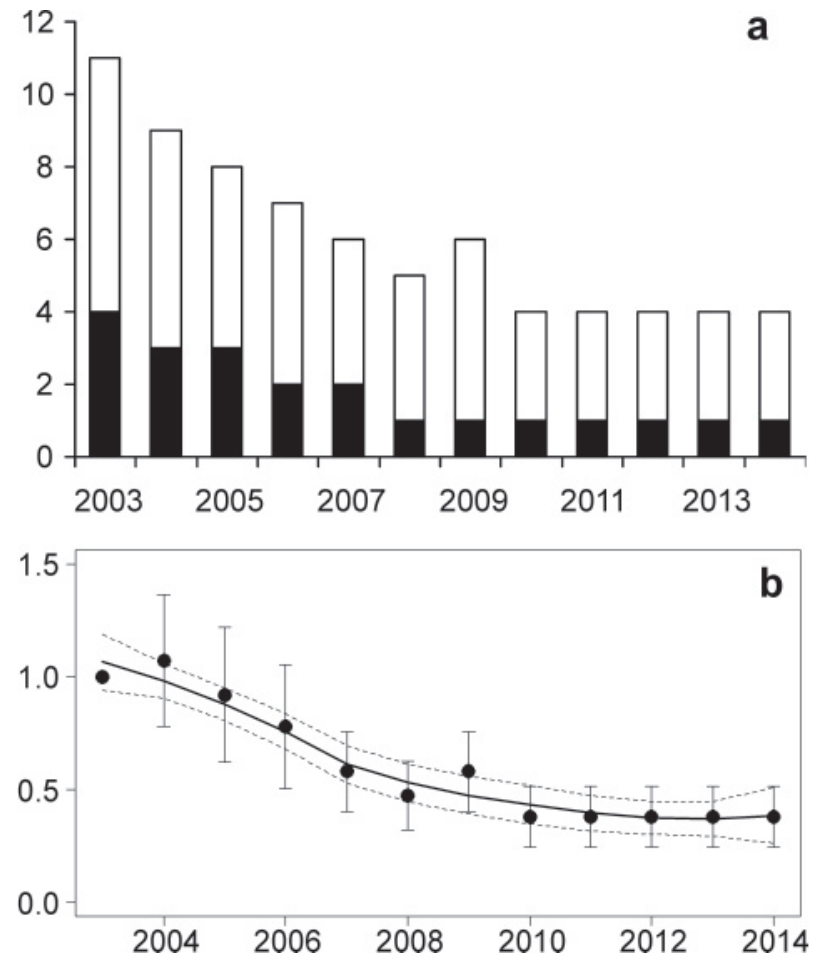

Fig. 5. Total number of greater spotted eagle pairs (filled bars) and mixed pairs with the lesser spotted eagle (empty bars; a), and the annual population indices $( \pm S E)$ with the trend line (loess curve with $95 \% \mathrm{Cl}$ ) of the two groups together $(\mathrm{b})$, in the spotted eagle plots.

Obr. 5. Počet čistých párov orla hrubozobého (plné stípce) a párov zmiešaných s orlom kriklavým (prázdne stípce; a); ročné populačné indexy ( \pm štandardná chyba) $s$ trendovou čiarou (loess-krivka s $95 \%$ intervalom spol'ahlivosti) spolu čistých aj zmiešaných párov (b) z monitorovacích plôch pre orla krikl'avého a hrubozobého.

low level (Fig. 5b). Both numbers of pure-species pairs and mixed pairs have decreased, but the decline in purespecies pairs has been stronger; their proportion has decreased from a third to a quarter of the greater spotted eagle breeding territories.

Changes in population composition are well illustrated by the data from the largest spotted eagle monitoring plot near Tartu (Fig. 6). The greater spotted eagle has always formed only a small part of the population. There were two greater spotted eagle pairs in the late 1990s (one of them was occupied by a mixed pair in the late 1980s and early 1990s) but both disappeared in the early 2000s. Three mixed pairs, with greater spotted eagle females, have decreased to one, with a breeding

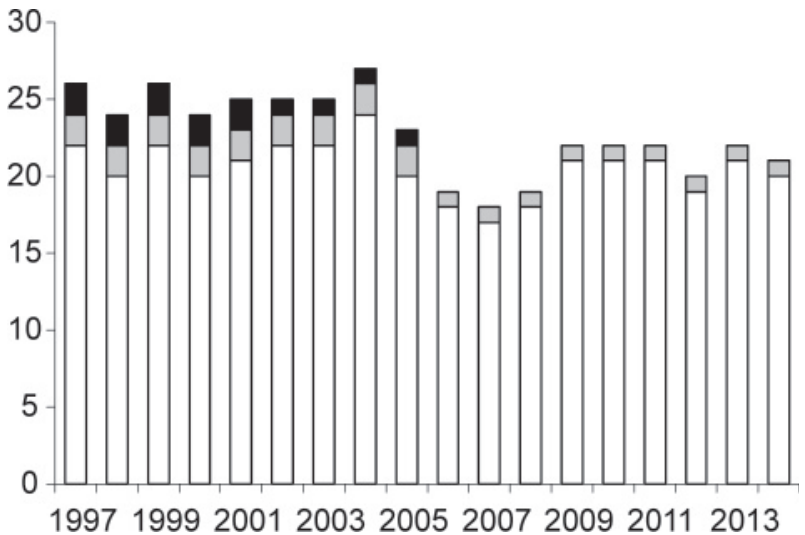

Fig. 6. Dynamics and composition of the spotted eagle subpopulation in the Tartu spotted eagle study area $\left(1000 \mathrm{~km}^{2}\right)$. Greater spotted eagle pairs are indicated as black, mixed pairs as grey and lesser spotted eagle pairs or single individuals as white.

Obr. 6. Dynamika a zloženie populácie orla kriklavého a hrubozobého na monitorovacej ploche pre tieto druhy orlov $v$ Tartu $\left(1000 \mathrm{~km}^{2}\right)$. Čisté páry orlov hrubozobých sú znázornené čierne, zmiešané sivo a páry alebo jednotlivé jedince orlov krikl'avých bielo.

hybrid male who remained single in 2013. Surprisingly, in 2014 a female greater spotted eagle arrived in his territory, but the pair did not start breeding.

A similar trend has been seen in raptor plots where in the late 1990s and early 2000s two pure-species pairs and at least two mixed pairs were breeding, while in 2014 only one hybrid individual bred with a lesser spotted eagle. The population trend for the 1990s is hard to estimate since mixed pairs and hybrids may have been missed in raptor plots at that time due to difficulties in identification. For instance, several mixed pairs have been found only after a genetic survey. However, according to the data from all raptor plots, the density of the greater spotted eagle/hybrid territories (pure-species pairs and mixed pairs pooled) declined from 0.375 pairs $/ 100 \mathrm{~km}^{2}$ in 1995 to 0.24 pairs $/ 100 \mathrm{~km}^{2}$ in 2002 and 0.07 pairs $/ 100 \mathrm{~km}^{2}$ in 2014 . The overall mean density over the years was 0.17 pairs $/ \mathrm{km}^{2}$ and that among plots was 0.10 pairs $/ 100 \mathrm{~km}^{2}$. The comparative data from the spotted eagle plots were rather similar, though somewhat higher: mean density decreased from 0.28 pairs $/ 100 \mathrm{~km}^{2}$ in 2003 to 0.14 pairs $/ 100 \mathrm{~km}^{2}$ in 2014 , the overall mean density over the years was 0.20 pairs $/ 100 \mathrm{~km}^{2}$ and that 
among plots was 0.18 pairs $/ 100 \mathrm{~km}^{2}$.

\section{Discussion}

The current study demonstrates the stability of the lesser spotted eagle and the steep recent decline of the greater spotted eagle population in Estonia over the previous two decades.

The stability of the lesser spotted eagle population has been taken into account in estimating the size of the Estonian population, being some $600-700$ pairs (Elts et al. 2013), but not yet deserving further attention. The stable trend is remarkable however, as several European populations such as those in Germany (Langgemach \& Böhner 2004, Langgemach et al. 2005), Lithuania (Treinys et al. 2007), and locally also in Latvia (Bergmanis et al. 2006, Bergmanis et al. 2015), have been declining over the last decades. Despite the stability, and even a probable increase in the last two years, one should not consider the lesser spotted eagle as being safe in Estonia. The numbers of the species should be carefully continuously monitored in Estonia as potential threats for nesting areas (logging) remain and those for the foraging grounds (replacement of meadows with arable land) have been increasing (Abel 2014). One of the most significant threats affecting the lesser spotted eagle in Estonia is the increasing production of rapeseed oil (Väli et al, in prep.). There has been remarkable widening of the area covered by rape fields during the recent two decades, from 600 hectares in 1990 to 98000 hectares in 2010 , although in recent years their area has somewhat decreased (to 80000 hectares in 2014 (Statistics Estonia 2015). Whether the contraction of rape production has been sufficient to improve the situation of the lesser spotted eagle in Estonia remains a topic for further studies. On the other hand, a new potential threat has (re-)appeared: the growing area of maize has increased from 900 hectares in 2007 to 7400 in 2014 and the trend is going steeply upwards (Statistics Estonia 2015).

In long-lived species reproductive success is an important monitoring parameter as it often signalises the impact of threats earlier than numbers do. Fortunately, no negative trends in breeding frequency, breeding success or productivity of the lesser spotted eagle have been recognised in Estonia, but all these breeding parameters fluctuate remarkably on a regular basis (Väli et al. 2005, Väli 2012). Despite the general stability, there seem to be some minor ups and downs also in the numbers of the lesser spotted eagle (Fig. 4), though with much less range and regularity. One could suspect that changes in breeding numbers of species may just be caused by the detectability determined by breeding success as birds are forced to hunt more and are thus more visible when they have offspring at the nest. However, fluctuations in numbers and productivity are not synchronous, so this is probably not always true. One must admit though that there have been some changes in study intensiveness across plots, but this too has not been synchronous and thus should not have a significant effect. Obviously, years of high breeding success must at least to some extent also have a real influence in philopatric species, as more birds are available to be incorporated into the breeding population after a time lag equal to the age of the first breeding. The relationship is not directly reflected in numbers because several other factors influence birds too. The most important of these is the first migration, which is fatal to many young birds (Meyburg et al. 2005 and unpubl. data). Environmental conditions at the wintering grounds may be unsuitable as well, and movements of immatures could bring them to hostile sites thus increasing their mortality. Even if young birds reach maturity, incorporation into the breeding population is not easy as breeding grounds may already be saturated with territorial birds. The breeding density of the lesser spotted eagle is rather low in Estonia compared to the other European countries (Meyburg et al. 2001), and even in neighbouring Latvia local densities reach several times higher levels (Bergmanis et al. 2006, Bergmanis et al. 2015). So there should be potential for an increase of numbers in Estonia, though not necessarily, as it is very difficult to estimate the actual carrying capacity of the Estonian environment for the species.

The data from the monitoring plots quantified the declining trend of the greater spotted eagle in Estonia, which has been shown and discussed earlier using the records of breeding territories and nests from all over the country (Väli et al. 2005, Väli et al. 2010a, Väli 2011, Väli et al. 2011). Summarizing all the existing data one can conclude that altogether $5-10$ breeding territories of the greater spotted eagle may be found currently in Estonia, most of them occupied by pairs interbreeding with the lesser spotted eagle. Several threat factors such as loss of old-growth wet forests and wet meadows have probably influenced the population in the past (Väli \& Lõhmus 2000, see also Maciorowski et al. 2014). These factors, however, are not considered as urgent threats in Estonia nowadays, because all known nest sites from the last two decades are protected and 
Väli Ü: Monitoring of spotted eagles in Estonia in 1994-2014: Stability of the lesser spotted eagle (Aquila pomarina) and decline of the greater spotted eagle (A. clanga)

large-scale measures to save habitats have been reinforced (Nurmla et al. 2015). The reproductive success seems to be sufficient in Estonia and existing pairs have bred successfully (Väli et al. 2005). At the same time, disappearing adult birds have usually not been replaced by young. Thus a major factor for the decline is probably mortality of young birds during migration or wintering, or their dispersal to breed in other areas. Several greater spotted eagles, studied by telemetry, have indeed been shot during migration, so this seems to be an important threat for the species (Maciorowski et al. 2014). Concerning dispersal, an interesting example is the behaviour of a satellite-tracked male greater spotted eagle who has not started breeding at the age of six years but has been a vagrant or holding a summer territory instead in Scandinavia, far from the currently known distribution range of the species (Väli and Sellis, in prep.). Hybridisation too, which itself is a consequence of declining numbers, has become an additional threat factor, as pair-bonds of eagles last for several years and incoming greater spotted eagles can not replace lesser spotted eagles breeding with other greater spotted eagles in the previous territories of the latter species (Lõhmus \& Väli 2005, Väli et al. 2010a). Whatever the reasons, the decline of the greater spotted eagle is a general process across Europe (BirdLife International 2015) and thus the shrinking of their range is not surprising. This obviously brings along the disappearance of subpopulations at range margins, such as the Estonian one, even if local conditions have not worsened.

Monitoring numbers of birds of prey is problematic because of their low densities over extensive areas. Monitoring programmes should therefore be conducted over a sufficiently large total area (Saurola 1986). Estimating the population size is especially problematic in birds with patchy distribution, such as the greater spotted eagle, or with gradual differences in density, such as the lesser spotted eagle in Estonia (Lõhmus 1998, Väli and Lõhmus 2000, Lõhmus and Väli 2001, Väli et al. 2005). Indeed, in the current study surprisingly many greater spotted eagles were recorded in the monitoring plots, in pure-species or mixed pairs, compared to their low total numbers in Estonia. Certainly this density should not be extrapolated to the entire country, or beyond, as several studied areas are located near large rivers with extensive floodplains, which are the best areas for the species in Estonia. Similarly, the breeding density of the lesser spotted eagle decreases gradually towards the north-west, where several raptor study plots are located, and the densities found in the current study should not be used for estimating its population size.

Both approaches are still valid for estimating population trends. Here, however, an intriguing question raises, analogous to the classical SLOSS debate in conservation biology: are single (few) large areas better than several smaller areas, or vice versa. The large special spotted eagle study areas provided a high total number of pairs, which was sufficiently large for conclusions on each subpopulation (plot), and the entire Estonian population of the lesser spotted eagle with rather small annual standard errors. The data were sufficient even for analysing the trend for the rare greater spotted eagle. Nevertheless, pairs in the same plot are not independent study units and pseudo-replication is a potential threat for any analysis of such data. To make reliable conclusions, the effort by researchers in extensive areas must be large, but this results in conclusions on the species in focus alone. In the second approach, the grid of raptor plots, the number of study plots was higher and these plots were scattered across the country, thus the number of independent study units was much higher. The number of spotted eagle pairs in every plot is small however, and stochastic effects may have played a significant role. Probably therefore the raptor plots suggested stronger fluctuations in abundance of the lesser spotted eagle, but the significance of fluctuations was covered by the large standard errors. The total number of studied pairs was rather small even for the more abundant lesser spotted eagle, and clearly insufficient to analyse trends in the greater spotted eagle. The working effort is large in raptor plots too, but this returns adequate conclusions on several other species, thus improving the cost-effectiveness of working hours for a broad-minded raptor biologist. It is hard to choose one approach for recommendation, as both have pros and cons, and complement each other. The choice has to be made by every researcher taking into account the purpose, region, time and the species of interest.

\section{References}

Abel U 2014: Väike-konnakotka kaitse tegevuskava projekt aastateks 2014-2018 [The project of the National action plan for the lesser spotted eagle in Estonia, 2014-2018]. Kotkaklubi, Tartu, 55. [In Estonian]

Bergmanis U, Petrinšs A, Cīrulis V, Granāts J, Opermanis O \& Soms A 2015: Population size and population dynamics of the lesser spotted eagle (Aquila pomar- 
ina) in Latvia over the last decade. Slovak Raptor Journal 9: 45-54. DOI: 10.1 51 5/srj-201 5-0003.

BirdLife International 2004: Birds in Europe: population estimates, trends and conservation status. BirdLife Conservation Series No. 12. BirdLife International, Cambridge, 374.

BirdLife International 2015: Species factsheets: Clanga clanga, Clanga pomarina. Retrieved February 11, 2015, from http://www.birdlife.org.

Elts J, Leito A, Leivits A, Luigujõe L, Mägi E, Nellis R, Nellis R, Ots M \& Pehlak H 2013: Eesti lindude staatus, pesitsusaegne ja talvine arvukus 2008-2012 [Status and numbers of Estonian birds in 2008-2012]. Hirundo, 26: 80-112. [In Estonian with English summary]

Forsman D 1999: The raptors of Europe and the Middle East: A Handbook of field identification. Poyser, London, 589.

Hardey J, Crick H, Wernham C, Riley H, Etheridge B \& Thompson D 2009: Raptors: A field guide for surveys and monitoring. Second edition. Scottish National Heritage, Edinburgh, 370.

Langgemach T, Scheller W \& Weber M 2005: The lesser spotted eagle Aquila pomarina in Germany - recent data on population, population trend, reproduction and threats, 153-159. In: Mizera T \& Meyburg B-U (eds): International meeting on spotted eagles (Aquila clanga, A. pomarina and $A$. hastata) - Research and conservation. Biebrza National Park, Osowiec, Poznań, Berlin, 268.

Langgemach T \& Böhner J 2011: Modelling the population dynamics of the lesser spotted eagle Aquila pomarina in Brandenburg: What are the effects of years with extremely low reproduction? Vogelwelt 132: 93-100.

Lelov E 1991: Breeding raptors and owls at Halinga, SW Estonia, in 1978-1989. Ornis Fennica 68: 119-122.

Lõhmus A 1994: Kulliliste ja kakuliste seire tänapäeva Eestis [Monitoring of raptors and owls in Estonia]. Hirundo 1994 (2): 31-45. [In Estonian with English summary]

Lõhmus A 1998: Suur- ja väike-konnakotka arvukusest Eestis [The numbers of the greater and lesser spotted eagle in Estonia]. Hirundo 11: 24-34. [In Estonian with English summary]

Lõhmus A 2004: Eesti röövlinnuseire 1999-2003: kanakulli kadu ja hiiretsüklite kellavärk [Monitoring of raptors and owls in Estonia, 1999-2003: decline of the Goshawk and the clockwork of vole-cycles]. Hirundo 17: 3-18. [In Estonian with English summary]

Lõhmus A \& Väli Ü 2001: Numbers and population dynamics of the lesser spotted eagle Aquila pomarina in Estonia. Acta Ornithoecologica 4 (2): 291-295.

Lõhmus A \& Väli Ü 2001: Interbreeding of the greater Aquila clanga and lesser spotted eagle $A$. pomarina. Acta Ornithoecologica 4 (2): 377-384.

Lõhmus A \& Väli Ü 2005: Habitat use by the vulnerable greater spotted eagle Aquila clanga, interbreeding with the lesser spotted eagle Aquila pomarina in Estonia. Oryx 39: 170-177. DOI: 10.1017/ S0030605305000414.

Maciorowski G Lontkowski J \& Mizera T 2014. The spotted eagle - vanishing bird of the marshes. Unigraf, Bydgoszcz-Poznań, 303.

Maciorowski G \& Mirski P 2014. Habitat alteration enables hybridisation between lesser spotted and greater spotted eagles in north-east Poland. Bird Conservation International, 24: 152-161.

Meyburg B-U, Belka T, Danko S, Wójciak J, Heise G, Blohm T \& Matthes H 2005: Geschlechtsreife, Ansiedlungsentfernung, Alter und Todesursachen beim Schreiadler Aquila pomarina. Limicola 19: 153-179.

Meyburg B-U, Haraszthy L, Strazds M \& Schäffer N 2001: European species action plan for the lesser spotted eagle. In: Schäffer N \& Gallo-Orsi U (eds). European Union action plans for eight priority bird species. European Commission, Luxembourg, 247.

Nurmla A, Nellis R \& Väli Ü 2014: Suur-konnakotka kaitse tegevuskava projekt aastateks 2014-2018 [The project of the National action plan for the greater spotted eagle in Estonia, 2014-2018]. Kotkaklubi, Tartu, 31. [In Estonian]

Pannekoek J \& Van Strien A 2005: TRIM 3 Manual. (TRends and Indices for Monitoring data). Statistics Netherlands, Voorburg, 57.

Pchelintsev VG 2006: Distribution and abundance of some raptor species in the Leningrad region, 120-124. In: Koskimies P \& Lapshin NV (eds), Status of raptor populations in eastern Fennoscandia. Proceedings of the Workshop 8-10 November 2005, Kostomuksha, Karelia, Russia. Karelian Research Centre of the Russian Academy of Science, Petrozavodosk, 184.

Randla T 1976: Eesti röövlinnud [Estonian Birds of Prey]. Valgus, Tallinn, total number of pages. [In Estonian with English summary] 
Tuule E, Tuule A \& Lõhmus A 2011: Fifty-year dynamics in a temperate raptor assemblage. Estonian Journal of Ecology 60: 132-142. DOI: 10.3176/eco.2011.2.04.

Treinys R, Drobelis E, Šablevičius B, Naruševičius V, Petraška A 2007: Changes in the abundance of the lesser spotted eagle (Aquila pomarina) breeding population in Lithuania in 1980-2006. Acta Zoologica Lituanica 17: 64-69.

Saurola P 1986: The raptor grid: an attempt to monitor Finnish raptors and owls. Vår Fågelvärld Suppl. 11: 187-190.

Statistics Estonia 2015. Statistical database. Retrieved February 2, 2015, from http://www.stat.ee/ee.

Väli Ü 2010: Successful breeding of a ten-year-old hybrid spotted eagle Aquila clanga x A. pomarina retaining immature plumage characters. Ardea 98: 235-241. DOI: 10.5253/078.098.0214.

Väli Ü 2011: Numbers and hybridisation of spotted eagles in Estonia as revealed by country-wide field observations and genetic analysis. Estonian Journal of Ecology 60: 143-154. DOI: 10.3176/ eco.2011.2.05.

Väli Ü 2012: Factors limiting reproductive performance and nestling sex ratio in the lesser spotted eagle Aquila pomarina at the northern limit of its distribution range: the impact of weather and prey abundance. Acta Ornithologica 47: 157-168. DOI: $10.3161 / 000164512$ X662269.

Väli Ü \& Lõhmus A 2000: The greater spotted eagle and its conservation in Estonia. Hirundo Supplementum 6. Eesti Ornitoloogiaühing, Tartu, 50.

Väli Ü \& Lõhmus A 2004: Nestling characteristics and identification of the lesser spotted eagle Aquila pomarina, greater spotted eagle $A$. clanga, and their hybrids. Journal of Ornithology 145: 256-263.
DOI 10.1007/s10336-004-0028-7.

Väli Ü, Lõhmus A \& Sellis U 2005: The greater spotted eagle in Estonia: numbers, distribution, productivity, diet and conservation, 53-60. In: Mizera T \& Meyburg B-U (eds) International meeting on spotted eagles (Aquila clanga, A. pomarina and A. hastata) Research and conservation. Biebrza National Park, Osowiec, Poznań, Berlin, 268.

Väli Ü, Dombrovski V, Treinys R, Bergmanis U, Daroczi SJ, Dravecky M, Ivanovski V, Lontkowski J, Maciorowski G, Meyburg B-U, Mizera T, Zeitz R \& Ellegren H 2010a. Widespread hybridization between the greater spotted eagle Aquila clanga and the lesser spotted eagle A. pomarina (Aves: Accipitriformes) in Europe. Biological Journal of the Linnean Society 100: 725-736. DOI: 10.1111/j.1095-8312.2010.01455.x.

Väli Ü, Saag P, Dombrovski V, Meyburg B-U, Maciorowski G, Mizera T, Treinys R \& Fagerberg S 2010b. Microsatellites and single nucleotide polymorphisms in avian hybrid identification: a comparative case study. Journal of Avian Biology 41: 34-49. DOI: 10.1111/j.1600-048X.2009.04730.x.

Väli Ü, Männik R, Nellis R, Sein G \& Tuvi J 2011: Eesti kotkaste seire: näiteid haruldaste liikide staatuse ja arvukuse määramisest [Monitoring Estonian eagles: examples of estimating status and numbers of rare species], 92-106. In: Kull T, Liira J \& Sammul M (eds). Eesti Loodusuurijate Seltsi Aastaraamat. Eesti Looduseuurijate Selts, Tartu, total number of pages. [In Estonian with English summary]

Valkama J, Vepsäläinen V \& Lehikoinen A 2011: 3rd Finnish bird atlas. Finnish Museum of Natural History and The Ministry of the Environment. Retrieved April 15, 2015, from http://atlas3.lintuatlas.fi. 